\title{
Józefa Życińskiego koncepcja życia społecznego
}

Ks. DR TOMAsZ ADAMCZYK

Katolicki Uniwersytet Lubelski Jana Pawła II

Postać Arcybiskupa Józefa Życińskiego była znana w wielu różnych kręgach społecznych. Jako przedstawiciel Kościoła katolickiego pełnił ważne funkcje w instytucjach watykańskich i w Episkopacie Polski. Był również członkiem różnych gremiów naukowych, wśród których warto wspomnieć Europejską Akademię Nauk i Sztuk w Salzburgu czy Rosyjską Akademię Nauk Przyrodniczych. Swoje wykłady wygłaszał między innymi na Uniwersytetach w Oksfordzie, Berkley, Princeton, Notre Dame czy Sydney. Jego dorobek naukowy to ponad 70 książek i kilkaset artykułów publikowanych w czasopismach krajowych i zagranicznych. Z wykształcenia był przede wszystkim filozofem i teologiem, ale jego wszechstronność naukowa i dynamika osobowościowa sprzyjały spotkaniom naukowym i analizom, nad którymi dzisiaj pochylają się również prawnicy, fizycy, matematycy, biolodzy.

Przyjaciel i współpracownik Józef Życińskiego, ks. prof. Michał Heller, w napisanym po śmierci Arcybiskupa 
artykule Filozoficzny program Józefa Życińskiego zauważa: „znałem twórczość Życińskiego, przecież w jego przedbiskupich latach w znacznej mierze pracowaliśmy razem, ale dopiero teraz, przeglądając jego publikacje na potrzeby tego opracowania, zorientowałem się, że wyłania się z nich spójny program filozoficzny. Przedtem fakt ten umykał mojej uwadze: sądzę, że nie tylko mojej". Swoje rozważania Michał Heller kończy podtytułem „Dzieło niedokończone”, gdyż wymaga ono rozwinięcia i kontynuacji w intelektualnej sztafecie pokoleń, jak często o tym mówił Arcybiskup z Lublina. O jego nieskończonym dziele świadczy również fakt opublikowania po jego śmierci kilku książek, które nie były oddane do druku przez samego autora, a zachowały się w formie luźnych notatek czy plików zapisanych w jego osobistym komputerze.

Kiedy dokonuje się analizy dorobku abp. Życińskiego z perspektywy nauk społecznych, można dostrzec elementy układające się w pewną całość. Szczegółowa ich naukowa analiza wymagałaby jednak rozbudowanego akademickiego studium. Na potrzeby niniejszego wywodu uwaga zostanie zwrócona tylko na wybrane idee w jego koncepcji życia społecznego. Trzeba zaznaczyć, że w analizie dorobku abp. Życińskiego pojawiają się pewne trudności. Różne sfery jego funkcjonowania - był przecież biskupem, profesorem, intelektualistą, publicystą - łączyły się z różnymi

1 M. Heller, Filozoficzny program Józefa Życińskiego, „Zagadnienia Filozoficzne w Nauce" 43 (2011), s. 5. 
formami jego wypowiedzi (homilie, wywiady, przemowy podczas spotkań okolicznościowych, wykłady akademickie, konferencje naukowe i pastoralne, książki stricte naukowe i popularyzatorskie, felietony). W tych różnych formach wypowiedzi można odnaleźć pewne cechy wspólne i charakterystyczne dla jego myśli.

Podczas konferencji naukowych poświęconych abp. Życińskiemu, które odbyły się po jego śmierci, często oprócz refleksji naukowych pojawiają się związane z nim osobiste wspomnienia. Arcybiskup Życiński w swoich wystąpieniach i wykładach bardzo często odnosił się również do osobistych doświadczeń, co dynamizowało jego wypowiedzi i nadawało im niepowtarzalny charakter. Także w naszym wypadku prowadzone analizy zostaną wzbogacone osobistymi wspomnieniami. Bedą one uzasadnieniem ostatniego elementu analiz, wyrastającego $z$ tradycji intelektualnej starożytnej Grecji, a dziś, wydaje się, nieco mniej eksponowanego w dorobku naukowym poszczególnych akademików.

\section{Naukowe inspiracje}

W formowaniu się filozoficznych poglądów Józefa Życińskiego można wyróżnić różne etapy i wskazać wpływ lektur i osób kształtujących jego myśl. We wczesnych latach młodości swoje zainteresowania filozoficzne rozwijał, sięgając przede wszystkim po dzieła przedstawicieli personalizmu, czytał również św. Augustyna czy św. Tomasza z Akwinu. Wpływ na jego formację intelektualną, ale 
również postawę życiową miał zwłaszcza ks. prof. Kazimierz Kłósak, promotor jego kilku prac naukowych. Zajmował się on myślą chrześcijańską otwartą na dialog z naukami przyrodniczymi. W tym okresie abp. Życiński interesował się również myślą scholastyczną. Wspominał, że uczyła go ona odpowiedzialności za słowo, naukowej ścisłości oraz umiejętności wprowadzania dystynkcji, a później w swoich pracach ukazywał korzenie humanizmu w scholastyce. Ważnym okresem w jego życiu była przyjaźń i wspólna praca ze wspomnianym już Michałem Hellerem. To on skierował uwagę Życińskiego w stronę filozofujących fizyków, rozpoczynając jego większe naukowe zainteresowanie nurtem platońskim².

Duży wpływ na sposób filozofowania abp. Życińskiego wywarł Alfred N. Whitehead, w którego twórczości naukowej dostrzegał on „otwartość na poszukiwanie prawdy w różnych płaszczyznach przy pomocy odmiennych założeń i zróżnicowanych metod"s. Whiteheadowski wpływ będzie również widoczny w jego odniesieniu do kategorii prawdy oraz intelektualizacji mistycyzmu. Pisząc o twórczości Whiteheada, Życiński zauważa: „filozofia jest bliska poezji z tej racji, że nie zamyka się ona w powtarzaniu stereotypowych konstatacji, lecz uwrażliwia na nowe aspekty rzeczywistości, rodzi nowe kwestie, podejmuje

2 Niewidzialne światto. $Z$ abp Józefem Życińskim rozmawiają Dorota Zańko i Jarosław Gowin, Kraków 2003, s. 211.

3 J. Życiński, Metafizyka o smaku przygody, w: Pasja wiedzy. Między naukq a filozofią, red. M. Heller, J. Życiński, Kraków 2010, s. 12. 
próby własnej interpretacji świata. Celowości tego typu procedury nie będą mogły pojąć osoby o mentalności zadowolonych biurokratów. Osoby te operują rutyniarsko schematami pojęciowymi i nie potrafią zdobyć się na refleksję odsłaniającą całą głębię treści stosowanych pojęć. Filozofię różni jednak od poezji metodologiczna ścisłość, dzięki której może ona upodobnić się do analiz matematycznych. W metafizyce, podobnie jak w matematyce, należy cenić formalne piękno sytemu, unikać wewnętrznych sprzeczności, nie obawiać się wyprowadzania konsekwencji odległych od rzeczywistości codziennych doświadczeń. By móc uprawiać filozofię w podobnym stylu, potrzeba nowego systemu pojęciowego, odmiennych terminów, poszerzenia perspektywy". Kategoria piękna, często przywoływana przez Życińskiego, nie była związana tylko $z$ estetyką. Transcendentalne pojęcie piękna było w jego twórczości naukowej równie ważne jak dominująca w środowisku akademickim kategoria prawdy. Widać tu element platoński w jego myśli, a także zakorzenienie w filozofii współczesnej - zarówno u Whiteheada, jak i fizyków odsłaniających matematyczną strukturę rzeczywistości. W tej metaetyczności świata abp. Życiński dostrzegał korzeń piękna, co jest ważną i oryginalną ideą dostrzegalną w jego myśli.

W formacji chrześcijańskiej Życińskiego ważną rolę odegrał Sobór Watykański II. Jego idę̨ odczytywał jako

\footnotetext{
4 Tamże.
} 
powrót do religijnego „najczystszego źródła”. Wyrażał wdzięczność Opatrzności, że mógł pracować w Kościele posoborowym. Nie oznaczało to łatwego odcinania się od przeszłości czy negatywnego postrzegania wcześniejszych etapów wspólnoty kościelnej. Był świadomy wpływu ducha epoki na sposób myślenia ludzi w danym okresie. Dokumentem soborowym „najbardziej fascynującym” była dlań Konstytucja duszpasterska o Kościele w świecie współczesnym Gaudium et spes ${ }^{5}$. Sobór Watykański II kształtował jego sposób myślenia, w którym otwartość na współczesność nie oznaczała zrywania z tradycją, a dialog był ważnym elementem etosu biskupa i intelektualisty.

Postacią, która w Kościele katolickim odcisnęła szczególne piętno na sposobie jego myślenia, był papież Jan Paweł II. Papieskie nauczanie często jest ważnym punktem odniesienia w wielu tekstach abp. Życińskiego. Potrafił je twórczo interpretować i rozwijać. Wydaje się, że można również stwierdzić, że Jan Paweł cenił Życińskiego, zapraszając go z wykładami do Castel Gandolfo na spotkania intelektualistów czy powołując do pełnienia ważnych funkcji, np. w Papieskiej Radzie Kultury czy Kongregacji ds. Wychowania Katolickiego. Warto także podkreślić, że ważna w dorobku Jana Pawła II encyklika Fides et ratio, traktująca o relacjach pomiędzy nauką a wiarą, była prezentowana właśnie przez abp. Życińskiego oraz kard. Josepha Ratzingera, późniejszego papieża Benedykta XVI.

5 Tamże s. 257-256. 


\section{Wizja antropologiczna}

Józef Życiński jako filozof przyrody ukazywał człowieka w kontekście długiej historii całego wszechświata. Współczesne odkrycia nauk przyrodniczych zakładają, że stan osobliwości początkowej, czyli wielki wybuch, miał miejsce 13,7 mld lat temu. Wszechświat więc rozwijał się bez ludzkiego obserwatora przez bardzo długi czas, a historia ludzkości stanowi niewielki ułamek dziejów wszechświata (zaledwie o,1\%). $Z$ jednej strony odkrycia nauki mogą budzić w świadomości ludzi poczucie kosmicznego wyobcowania, $\mathrm{z}$ drugiej zaś perspektywa miliardów lat kosmicznej ewolucji pomaga nabrać dystansu do bieżących wydarzeń ${ }^{6}$. Arcybiskup Życiński zauważał, że współczesny rozwój nauk przyrodniczych ukazuje coraz ściślejszy i wyrafinowany związek człowieka ze światem przyrody, z którym dialog może być prowadzony za pomocą języka matematyki. Spoglądając z perspektywy długiej historii wszechświata, Życiński podkreślał, że nie należy ubolewać nad minionym czasem z ery leptonowej czy plejstocenowej. Przed człowiekiem stoi wyzwanie, aby chronić kosmiczny Sens, pozostając wiernym wartościom, które składają się na małą ojczyznę ludzkiego gatunku. Istotne jest wówczas, aby harmonia i racjonalność Natury znajdywały swoje przedłużenie na poziomie kulturowych działań człowieka?.

6 Zob. J. Życiński, Wszechświat emergentny. Bóg w ewolucji przyrody, Lublin 2009, s. 7.

7 J. Życiński, Odyseusz czy playboy? Kulturowa odyseja człowieka, Kraków 2005, s. 92-94. 
W ujęciu Życińskiego współczesną istotną kwestią społeczną była wizja człowieka, czyli kwestia antropologii. Człowiek w jego koncepcji urzeczywistnia się poprzez kulturę. Był to dlań ważny fundament, który powinien tkwić u podstaw humanizmu. Osoba ludzka była dla Życińskiego wartością centralną, a wszystkie inne wartości były wobec osoby ludzkiej wtórne. Podkreślał, że wpływ na określoną koncepcję praw człowieka ma pojęcie osoby ludzkiej wypracowane w dyskusjach teologicznych, które dotyczyły relacji między osobą a naturą Trójcy Świętej, jak i w dyskusjach dotyczących relacji natury boskiej i ludzkiej w Chrystusie ${ }^{8}$. „Teologiczna prawda o zróżnicowaniu Osób Bożych obdarzonych tą samą naturą przyczyniła się do kształtowania klimatu intelektualnego, w którym szanowano odmienność cech osobowościowych, nie usiłując narzucić identycznych zachowań i własności wszystkim osobom. Teologiczne pojmowanie osoby ludzkiej tworzyło naturalną podstawę dla respektowania godności tej osoby"9. Ukazywał również wpływ chrześcijaństwa na rozwój idei humanistycznych, pisząc: „Po abstrahowaniu od mało istotnych, akcydentalnych czynników ludzkiej egzystencji, chrześcijaństwo wykraczało poza empiryczne fascynacje znamienne dla różnorodnych społeczeństw i kultur, kształtując wyrazistą wizję osoby ludzkiej, która rozwija

8 J. Życiński, Europejska wspólnota ducha. Zjednoczona Europa w nauczaniu Jana Pawła II, Warszawa 1998, s. 61-63.

9 Tamże, s. 62. 
się i doskonali w bliskiej więzi z osobami Bożymi" ${ }^{10}$. Arcybiskup Życiński w wielu swoich publikacjach pokazywał istotną rolę humanizmu chrześcijańskiego, stanowiącego ważny element kultury europejskiej.

Józef Życiński negatywnie oceniał pojawiający się w niektórych obszarach badań naukowych redukcjonizm antropologiczny, choćby w myśli Richarda Rorty'ego, kwestionującego samo pojęcie osoby ludzkiej. Krytycznie oceniał zjawisko posthumanizmu lub transhumanizmu, gdzie człowieka niekiedy przedstawiano jako istotę przejściową, którą można udoskonalać za pomocą technologii genetycznych. Tradycyjny humanizm i zasady etyczne były u niektórych przedstawicieli koncepcji posthumanizmu wyrazem jedynie przestarzałych konwenansów kulturowych, co spotykało się ze zdecydowaną krytyką Józefa Życińskiego ${ }^{11}$.

Życiński dostrzegał niebezpieczeństwo kolejnych rewolucji antropologicznych. Na przykład w koncepcji Jareda Diamonda homo sapiens określany jest mianem „trzeciego szympansa"12, a doktryna ukazująca człowieka jako istotę wyróżnioną w świecie przyrody jest, wedle niego, równie bezpodstawna jak wszelki rasizm czy seksizm. Niektórzy, rozwijając tezy Edwarda O. Wilsona, zaliczani byli do

10 Tamże, s. 62-63.

11 G. Herling-Grudziński, J. Życiński, Pięć dialogów, Warszawa 1999, S. 102.

12 J. Życiński, Wszechświat emergentny. Bóg w ewolucji przyrody, Lublin 2009, s. 94; P. Singer, O życiu i śmierci. Upadek etyki tradycyjnej, Warszawa 1997, s. 195. 
radykalnych przedstawicieli socjobiologii, a w swoich koncepcjach sprowadzali ludzką kulturę, z jej podstawowymi wartościami, w tym z godnością osoby ludzkiej, tylko do determinizmów genetycznych ${ }^{13}$.

Szczególnie negatywnie oceniana przez Arcybiskupa z Lublina była myśl Petera Singera, który głosił pogląd, że „zwierzęta mają takie samo albo większe prawo do życia jak ludzie upośledzeni psychicznie lub otępiali starcy" ${ }^{14}$. Życiński podkreślał: „Życie ludzkie jest nienaruszalne, ponieważ człowiek jest osobą. Bycie osobą nie zależy od parametrów biologicznych ani od wskaźników aktywności psychicznej. Bycie osobą nadaje człowiekowi specyficzną godność i różni go zarówno od innych istot żywych, jak i od świata rzeczy, decydując o naszej podmiotowości. Nie wolno w szczególności redukować osoby ludzkiej do jej genomu, ignorując cielesno-duchowe wartości istnienia konkretnego człowieka" ${ }^{15}$. Życiński ukazywał pozytywny przykład Francisa Fukuyamy, autora książek pod znamiennymi tytułami Koniec historii oraz Koniec człowieka, który widział obronę humanizmu w społeczeństwie wysokich technologii w chrześcijańskim personalizmie, zawartym w myśli

\footnotetext{
13 J. Życiński, Europejska wspólnota ducha, s. 69.

14 P. Singer, Praktische Ethik, Stuttgart 1984, s. 70.

15 J. Życiński, Między Hipokratesem a Singerem. Godność człowieka jako podstawa etyki medycznej, wykład wygłoszony podczas II Międzynarodowego Kongresu Polskiego Towarzystwa Medycyny Ratunkowej pt. Medycyna ratunkowa $w$ Europie Środkowo-Wschodniej, Lublin, 12-15 września 2004 r. (mps).
} 
Jana Pawła $\mathrm{II}^{16}$. Dla ochrony gatunku homo sapiens ważne jest respektowanie zarówno praw człowieka, jak i nienaruszalności ładu natury.

Za Janem Pawłem II pisał o potrzebie personalistycznego wymiaru globalizacji. Istotne będzie poszanowanie godności osoby ludzkiej, respektowanie praw człowieka oraz solidarność międzyludzka. Często odwoływał się do kategorii ecologia humana, przypominając, że słusznie troszcząc się o zachowanie naturalnego habitatu dla różnych gatunków zwierząt, dba się w wystarczający sposób o prawdziwą ekologię ludzką, która swój wyraz znajduje w trosce o ochronę warunków moralnych ${ }^{17}$. Dodawał przy tym argument teologiczny, że nie tylko ziemia została dana człowiekowi przez Boga, ale również sam człowiek jest Bożym darem ${ }^{18}$.

\section{Godność osoby ludzkiej}

Józef Życiński, często odwołując się do godności osoby ludzkiej, odróżniał godność osobową od osobowościowej. „O godności w sensie empirycznym, zwanej także godnością warunkową, mówimy w odniesieniu do konkretnych

${ }_{16}$ Zob. F. Fukuyama, Koniec historii, tłum. T. Bieroń, M. Wichrowski, Poznań 1996, 2000; F. Fukuyama, Koniec człowieka. Konsekwencje rewolucji biotechnologicznej, tłum. B. Pietrzyk, Kraków 2004.

17 Encyklika Centesimus annus, nr 38.

18 J. Życiński, Aksjologiczne aspekty globalizacji, w: Człowiek i polityka, red. J. Kłos, A. Noras, Lublin 2002, s. 329. 
ludzkich zachowań. W przyjętej praktyce językowej mówi się, że tak pojętą godność można zniszczyć, utracić, zagubić. Od godności empirycznej różni się istotnie godność w sensie filozoficznym lub teologicznym, nazywana też godnością bezwarunkową. Przysługuje ona każdej bez wyjątku osobie, jest podstawą praw człowieka i nikt nie może być jej pozbawiony" ${ }^{19}$. Stał na stanowisku, podzielanym także przez Organizację Narodów Zjednoczonych, że źródłem praw człowieka jest godność osoby ludzkiej. Sprzeciwiał się uzależnianiu godności osoby ludzkiej i praw człowieka od innych dodatkowych uwarunkowań. Istnieją koncepcje, wedle których prawa człowieka mają swoje źródło w aktach prawnych (konstytucje państwowe i konwencje międzynarodowe). $Z$ perspektywy nauczania Kościoła katolickiego takie rozwiązanie ma charakter relatywizujący, gdyż wówczas prawa człowieka uzależnione są od władzy, która je ustanawia. Arcybiskup Życiński, podkreślał, że każda istota ludzka posiada godność osobową i prawa człowieka. Są one kwestionowane jedynie w systemach totalitarnych ${ }^{20}$.

Dla lepszego zrozumienia jego stanowiska w kontekście polskich sporów lustracyjnych warto zauważyć, że w konflikcie godności osoby ludzkiej i prawdy Życiński

19 J. Życiński, Kultura godności czy dyktatura sukcesu?, w: Godność czy sukces. Kulturowe dylematy współczesności. Materiały III Kongresu Kultury Chrześcijańskiej. KUL, Lublin, 25-28 września 2008 r., red. J. Mariański,

S. Zięba, Lublin 2008, s. 11.

20 Tamże, s. 12. 
opowiadał się za prymatem godności. Uzasadniał, że godność osoby ludzkiej jest ważniejsza od prawdy, gdyż przysługuje ona każdemu człowiekowi, także osobie łamiącej wszelkie przypisy moralne i prawne. Przestępca nie jest pozbawiony godności osoby ludzkiej, którą należy uwzględniać na różnych etapach podejmowanych działań. Owej osobowej godności nie można ani utracić, ani jej zniszczyć. Życiński uzasadniał ją również teologicznie, odwołując się kategorii imago Dei. Uważał, że jest ona charakterystyczna zarówno dla Ewangelii, jak i dla kultury europejskiej ${ }^{21}$.

To, co głosił abp. Życiński, nie miało charakteru tylko teoretycznych rozważań. Chciałbym to zobrazować, odwołując się do charakterystycznego dlań stawania w obronie wielu osób. Po uporządkowaniu archiwum Arcybiskupa okazuje się, że zdecydowana większość przypadków (około 70\%), gdy Arcybiskup prosił o zwołanie konferencji prasowej czy spotkania dla mediów, dotyczyła sytuacji, kiedy wstawiał się za kimś lub kogoś bronił.

\section{Integracja aksjologiczna}

Józef Życiński w swoich publikacjach często poruszał problem wartości. Nie zajmował się ich definiowaniem czy klasyfikowaniem. W swoich tekstach i przemówieniach ukazywał wartości jako istotny czynnik konstytuujący grupę społeczną. „Wartości” są jednak pojęciem

${ }^{21}$ Tamże. 
niejasnym i spornym. Filozofia klasyczna odróżnia wartości ogólne o ważności absolutnej od wartości partykularnych, cechujących się względnością, i zajmuje się przede wszystkim tymi pierwszymi. Nauki szczegółowe, takie jak socjologia, psychologia, prawo czy ekonomia, koncertują się w swoich badaniach na wartościach faktycznie uznawanych, ukazując przede wszystkim to, co jest pożądane lub godne pożądania. W swoich analizach podkreślają uwarunkowanie wartości od czynników społecznych, osobowościowych, gospodarczych, potocznych itd. Nie przesądza to o nieistnieniu wartości absolutnych. W socjologii odróżnia się wartość od wartościowania, a przy tym niektórzy socjologowie odróżniają stały element konstytuujący wartości oraz różne sposoby ich urzeczywistniania ${ }^{22}$.

Józef Życiński zakładał istnienie obiektywnych wartości, niezależnych od działań politycznych i rozważania filozoficznych. Wśród nich wymieniał przede wszystkim wartości o charakterze transcendentalnym: prawdę, dobro, piękno. Kolejnymi wartościami niezależnymi od uwarunkowań społecznych i kulturowych są, w ujęciu abp. Życińskiego, godność osoby ludzkiej, wolność, solidarność, tolerancja i miłość bliźniego ${ }^{23}$. Nie było to ujęcie socjologiczne o charakterze deskryptywnym. W swoich tekstach podkreślał rolę wartości, dzięki którym człowiek

\footnotetext{
22 J. Mariański, Socjologia moralności, Lublin 2006, s. 333.

${ }_{23}$ J. Życiński, Bóg postmodernistów, Lublin 2001, s. 80.
} 
tworzył świat poezji i filozofii, rozwijał refleksję naukową i wartościowanie moralne. Zauważał, że zapomnienie o tych wartościach prowadzi do redukcji antropologicznej, która „kaleczy” zarówno naturę człowieka, jak i jego kulturę $e^{24}$. Arcybiskup pisał: „Po to, by nasze życie było autentycznie ludzkim, musi znaleźć się w nim sfera wartości absolutnych, których nie poświęcilibyśmy dla żadnych innych wartości. Zakres tej sfery zmienia się w konkrecie ludzkiego życia; zależy on zarówno od przyjętej filozofii życiowej, jak i od upływu czasu oraz związanych z nimi przeżyć. Tragiczne nieporozumienie pojawia się wówczas, gdy ktoś podniesie do rangi absolutu wartości pozorne lub względne"25. Koncentrował się nade wszystko na ukazaniu uniwersalizmu wartości.

Na skutek przemian społeczno-kulturowych łatwo jest współcześnie utracić poczucie więzi z przeszłością. Istotnym elementem jest podtrzymywanie związków z korzeniami kulturowymi istotnymi dla tradycji europejskiej. Aby tego dokonać, należy uwzględniać historyczne korzenie podstaw kulturowych, co nie musi być związane $\mathrm{z}$ absolutyzowaniem przeszłości i bezkrytycznym powielaniem historycznych schematów. Radykalne odcięcie się od przeszłości może być postrzegane jako ucieczka od sensu w kierunku absurdu i nihilizmu, gdy odrzuci się wartości podstawowe składające się na dorobek animal rationale. Wówczas

24 J. Życiński, Ziarno samotności, Kraków 1997, s. 98.
25 J. Życiński, Medytacje Sokratejskie, Lublin, 1991, s. 94. 
istnieje możliwość pojawienia się, według abp. Życińskiego, homo ludens, homo sovieticus czy homo pragmaticus. Odejście od wartości łączonych z tradycją intelektualną Hellady może prowadzić w kierunku nieskomplikowanych przygód Tarzana pozbawionego głębszej refleksji ${ }^{26}$. Arcybiskup nazywał ten proces „mentalnością prowincji”, próbą budowania "nowego Edenu”, do którego nie mają dostępu zwolennicy Sokratesa. Nawiązywanie do cywilizacji wywodzącej się ze starożytnych krajów basenu Morza Śródziemnego jest ważnym elementem myśli Arcybiskupa ${ }^{27}$. W ten sposób można dostrzec, że odwołuje się on również do źródeł pozareligijnych w uzasadnianiu swoich tez.

Wychodząc z historycznych doświadczeń składających się na bolesne doświadczenie XX wieku, abp. Życiński z niechęcią spogląda na próby budowania różnych systemów aksjologicznych alternatywnych wobec chrześcijaństwa. Wymienia trzy takie wielkie społeczne systemy aksjologiczne, które charakteryzowały się prostotą i radykalizmem i każdy z nich znalazł zwolenników w opiniotwórczych elitach: „nazistowska apoteoza rasy z antropologiczną wizją Übermenscha; marksistowska koncepcja przewodniej klasy i związany z nią kolektywizm społeczny; maoistowska wizja rewolucji kulturalnej, łączącej elementy metafizyki

26 J. Życiński, Chrześcijaństwo wobec nowych wyzwań kulturowych, w: Sacrum i kultura. Chrześcijańskie korzenie przyszłości, red. R. Rubinkiewicz, S. Zięba, Lublin 200o, s. 10.

${ }_{27}$ J. Życiński, Medytacje sokratejskie, dz. cyt., s. 5 . 
Wschodu z marksistowską koncepcją walki klas" ${ }^{28}$. Cechą charakterystyczną alternatywnych systemów aksjologicznych była negacja wcześniejszego sytemu wartości oraz wykorzystanie środków administracyjnych do wprowadzenia nowego. Łączyło się to z wprowadzaniem jednowymiarowej antropologii i zakwestionowaniem uniwersalistycznej wizji człowieka i kultury ${ }^{29}$.

Głębokie rozdarcie dostrzegał w przyjęciu wzajemnie wykluczających się wartości i akceptacji wykluczających się zasad. Wiązał to zwłaszcza z mentalnością postmodernistyczną i próbami ucieczki od konfliktów spowodowanych niespójnością systemu aksjologicznego, kiedy to niektórzy uciekają od ocen etycznych czy bezpośredniego odniesienia się do wartości związanych z tradycją judeochrześcijańską. „Przejawy takiego podejścia znajdujemy w wielu współczesnych propozycjach aksjologicznych, w których zbiór wartości zostaje zredukowany do poziomu pragmatyki czy estetyki. W perspektywie tej eliminuje się pojęcie honoru, odpowiedzialności czy uczciwości. W miejsce prawdy zostaje wprowadzona polityczna poprawność, natomiast pojęcie wolności uzyskuje tak rozmytą treść, że można z nim łączyć cokolwiek. W proponowanym ujęciu otrzymujemy nowy wariant filozofii «luzu» i pojętego specyficznie wyzwolenia. Człowiek, uwolniony zarówno

28 J. Życiński, Chrześcijaństwo wobec nowych wyzwań kulturowych, dz. cyt., s. 8.

29 Tamże, s. 11. 
z oświeceniowych złudzeń, jak i z ograniczeń niesionych przez chrześcijaństwo, jawi się jako istota wolna od kulturowego dziedzictwa dziejów, która może demonstrować swe upojenie wolnością, tańcząc i głosząc radość życia”o.

Józef Życiński, podobnie jak papież Benedykt XVI, dostrzegał niebezpieczeństwo relatywizmu. Polemizował z tezą Davida Bloora, współtwórcy Mocnego Programu Szkoły Edynburskiej, który zakładał, że prawda absolutna i uniwersalne wartości mają swoje jedyne uzasadnienie w uprzednio przyjętej religii. Polemizując z Bloorem, Życiński pisał: „Można podać wiele kontrprzykładów świadczących o fałszywości podobnej sugestii. W fizyce relatywistycznej absolutny charakter mają tzw. niezmienniki wobec transformacji Lorentza, których postać nie zależy od przyjętego układu. W antropologii niepoważnie wyglądałaby obrona rasizmu lub antysemityzmu. W etyce próba usprawiedliwienia stosowalności tortur czy pozytywna ocena moralna obozu w Auschwitz mają charakter jednoznaczny, wszelka zaś próba ich usprawiedliwienia stanowiłaby wyraz patologicznego radykalizmu. Skutkiem tego utożsamienie ze współczesną kulturą apologii relatywizmu stanowi wyraz upodobań interpretacyjnych, których nie sposób racjonalnie uzasadnić" ${ }^{31}$. W ten sposób abp. Życiński wyjaśnia, że istnienia wartości absolutnych i prawdy absolutnej nie uzasadnia jedynie religia. Za Janem Pawłem II

\footnotetext{
30 Tamże.

${ }^{31}$ J. Życiński, Kultura godności czy dyktatura sukcesu?, dz. cyt., s. 13.
} 
oraz Katechizmem Kościoła katolickiego podkreśla natomiast, że chrześcijanin nie może występować w roli posiadacza prawdy ostatecznej w całej pełni. Dodaje też, że nie można innym siłą narzucać dobra i prawdy. Prawda chrześcijańska nie należy do takiej kategorii. Odróżnia więc przekonanie o posiadaniu prawdy od wiary w jej istnienie ${ }^{32}$. Opowiada się jednak za optymizmem poznawczym i traktuje poszukiwanie prawdy jako niekończący się proces ${ }^{33}$.

Józef Życiński znany był z polemicznego temperamentu i dosadnych stwierdzeń. W jednym z wywiadów opublikowanych już po jego śmierci wspominał, jak na międzynarodowym spotkaniu w Jerozolimie zasugerował, aby w przygotowywanej deklaracji zamieścić obronę uniwersalnych wartości. Zaoponowała na to jedna z Amerykanek: „Proszę wybaczyć, ale ja nie wierzę w żadne uniwersalne wartości". Odpowiedział jej wówczas, że to nie jest kwestia wiary, ale racjonalnej argumentacji. Kiedy poprosiła, żeby podał jej przykład jakiejś uniwersalnej zasady, Arcybiskup odpowiedział: „Natura kobieca nie jest gorsza od męskiej”34.

\section{Synteza trzech kultur}

Kultura jest ważnym zagadnieniem w myśli Józefa Życińskiego. Jak wiadomo, był członkiem Papieskiej Rady

32 J. Życiński, Na zachód od domu niewoli, Poznań 1997, s. 181-183.

33 J. Życiński, Medytacje sokratejskie, dz. cyt., s. 7.

34 Świat musi mieć sens. Przerwana rozmowa arcybiskupa Józefa Życińskiego i Aleksandry Klich, Warszawa 2012, s. 13. 
ds. Kultury, i to od powołania tej dykasterii do istnienia. W homilii zaś podczas ingresu do archidiecezji lubelskiej 2007 roku zapowiedział realizację nowej inicjatywy w obszarze kultury, mówiąc: „W nowych realiach, które niosą obecnie wiele głębokich pytań, pragnąłbym, aby Lublin stał się wkrótce miejscem Kongresu Kultury Chrześcijańskiej. Pragnąłbym, aby zarówno środowisko KUL-u, jak i przedstawiciele środowisk niezależnych $\mathrm{z}$ kraju i zagranicy zespolili swe wysiłki, ukazując, w jaki sposób posługa myślenia i posługa artystycznej twórczości mogą zespolić się w odkrywaniu ukrytej głębi, która prowadzi do pełnego rozwoju osoby ludzkiej. Duch pojednania i ewangelicznego dialogu, kształtowany we wspólnej trosce o kulturę, niesie szansę nowej ewangelizacji w trudnych czasach przełomu tysiącleci. Jej warunkiem jest otwarcie Kościoła na wszystkich poszukujących" ${ }^{35}$. Teren kultury był dlań przestrzenią spotkania Kościoła z przedstawicielami różnych środowisk, nie zawsze związanych bezpośrednio z chrześcijaństwem. W lubelskim środowisku akademickim, które obejmowało wówczas sześć uczelni wyższych, widział szansę twórczej refleksji nad współczesną kondycją kultury. Istotnym elementem refleksji Józefa Życińskiego była troska o godność człowieka i personalistyczny wymiar społeczeństwa i kultury. Dla abp. Życińskiego, podobnie jak dla Floriana Znanieckiego, świat kultury był światem wartości będącymi elementem podstawowymi ludzkiego doświadczenia,

35 Tamże. 
którego nie można sprowadzać do kategorii przyrodniczych, stąd też każda kultura jest humanistyczna ${ }^{36}$.

Przyglądając się współczesnym przemianom kultury, umieszcza ją w kontekście rozszerzonej teorii ewolucji, nie odrywając człowieka ani od świata przyrody na wzór radykalnych humanistów, ani nie sprowadzając osoby ludzkiej tylko do wymiaru biologicznego. Za pomocą metody sokratejskiej bada pojawiające się we współczesnej kulturze napięcia, stawiając wiele ważnych pytań i diagnoz. Jego wizja kultury charakteryzuje się oryginalnością, choć nie czyni tego z pozycji gotowego syste$\mathrm{mu}^{37}$. W nawiązaniu do papieża Jana Pawła II jego koncepcja kultury zawiera elementy, które do Europy wniosło chrześcijaństwo: „1. antropologia połączona z autorefleksją nad ludzkim «ja», 2. teza o centralnej wartości osoby ludzkiej, 3. nieporównywalnej z niczym innym, 4. wiara w postęp w każdej dziedzinie, 5. nadzieja na zbudowanie świata opartego na sprawiedliwości i solidarności, 6. optymizm, w którym zło nie stanowi najwyższej instancji, 7. realizm, w którym dąży się do ideałów, mimo rozczarowań i niepowodzeń" ${ }^{38}$.

Józef Życiński ukazywał integracyjne możliwości chrześcijaństwa, które jednoczyło pomimo różnic Słowian, Germanów, Celtów oraz przedstawicieli kultury

36 F. Znaniecki, Nauki o kulturze. Narodziny i rozwój, Warszawa 1971.

37 A. Wierzbicki, Szeroko otwierat drzwi Kościoła, Lublin 2016, s. $147-148$.

${ }^{38}$ J. Życiński, Europejska wspólnota ducha, dz. cyt., s. 38. 
łacińskiej i anglosaskiej39. „Ten proces integrowania oddzielonych plemion nie dokonywał się na poziomie haseł politycznych. Jego głównym składnikiem było kształtowanie kultury inspirowanej aksjologią Ewangelii. Dokonywało się to często przez łączenie heterogennych składników, które usiłowano przeciwstawiać w radykalnych, uproszczonych wersjach wcześniejszych epok" ${ }^{{ }^{\circ}}$. $\mathrm{Na}$ tej podstawie Życiński za Janem Pawłem II opowiadał się za prymatem kultury w integracji europejskiej przed czynnikami politycznymi, gospodarczymi czy społecznymi.

Stanowisko abp. Życińskiego nie kontestowało faktu pluralizmu kultur. Dostrzegał semantyczną ambiwalencję i aksjologiczną niewystarczalność pojęcia pluralizmu. „Z jednej strony pluralizm to wielość faktów i wielość możliwości. Alternatywa symbolizuje dystans, a także brak konieczności, jest z istoty kulturotwórcza, dzięki niej dokonuje się identyfikacja wartości i ich wybór. Z drugiej strony pluralizm polega na fragmentaryzacji obrazu świata, posuniętej aż do ciasnoty umysłowej i postaw wykluczających możliwość innego ujęcia tej samej rzeczywistości. Ten typ pluralizmu niesie konflikt oraz walkę kultur. [...] Ale pluralizm to także spotkanie we wspólnocie sensu ludzi i środowisk wychodzących z odmiennych doświadczeń oraz odmiennych założeń". Podejmując omówienie wizji abp. Józefa Życińskiego dotyczących relacji kultury

\footnotetext{
39 Tamże, s. 39.

40 Tamże.
} 
chrześcijańskiej do pluralizmu obecnego we współczesnej kulturze, trzeba mieć na uwadze znaczeniowe niuanse samego pojęcia „pluralizm”. Co więcej, „sama kultura chrześcijańska nie jest monolityczna"41. Zjawisko pluralizmu według abp. Życińskiego nie neguje i nie podważa uniwersalizmu wartości. Ukazywał, że nie należy traktować nauki ani współczesnych odkryć przyrody jako zagrożenia dla chrześcijaństwa ${ }^{42}$. W myśli postmodernistycznej dostrzega on niespójności w ocenie tradycji oświeceniowej, gdzie deprecjonując rozum, naukę i tzw. wartości absolutne, ukazuje się tolerancję wraz z szacunkiem dla różnych mniejszości jako wartość niekwestionowalną i absolutną. Przestrzega przed nową formą imperializmu intelektualnego, gdy głosi się poglądy, iż wszystko jest względne, a prawda stanowi wynik uwarunkowań kulturowych ${ }^{43}$.

Oryginalnym elementem $w$ analizach dotyczących kultury jest u abp. Życińskiego synteza trzech jej dziedzin: kultury naukowej (racjonalnej), kultury artystycznej (jej symbolem może być poezja lub sztuka) i religijnej (duchowości). W swojej książce Trzy kultury abp. Życiński pisze o automatyzacji wspomnianych trzech dziedzin kultury, poszukuje metodologicznie poprawnej syntezy, aby znaleźć pełniejszą wizję humanizmu. Konflikt między przyrodniczym, artystycznym, religijnym wymiarem kultury powodowany

${ }^{41}$ A. Wierzbicki, Szeroko otwierał drzwi Kościoła, dz. cyt., s. 148-149.

${ }_{42}$ Zob. J. Życiński, Bóg i stworzenie. Zarys teorii ewolucji, Lublin 2011, S. 12.

43 G. Herling-Grudziński, J. Życiński, Pięć dialogów, dz. cyt., s. 15. 
był totalizmem intelektualnym, który zakładał tylko jeden prawomocny opis rzeczywistości. „Podzielając to przekonanie, przedstawiciele nauki rezerwowali dla niej wyłączne kompetencje do wyjaśniania świata, poeci i artyści czuli się zagrożeni, iż rozwój nauk uszczupla z konieczności zasięg dziedziny piękna, natomiast myśliciele religijni wprowadzali swoistą rywalizację między funkcjonowaniem przyczyn naturalnych a działaniami Ostatecznej Przyczyny"44. Pomijanie jednej z dziedzin kultury będzie prowadziło do redukcyjnego jej ujęcia i nie pozwoli na ukazanie pełnego ludzkiego doświadczenia.

Józef Życiński w przeciwieństwie do znanego profesora socjologii Leona Dyczewskiego, też zajmującego się kulturą, nie chciał tworzenia alternatywnej katolickiej kultury. Miała ona powstawać wskutek coraz większego rozdźwięku pomiędzy współczesną kulturą a humanizmem chrześcijańskim. Charakteryzowałaby się niezależnością od panujących współcześnie trendów kulturowych i pozostawałaby wierna tradycji chrześcijańskiej ${ }^{45}$. Życiński nie chciał tworzyć chrześcijańskiego getta. Nie uważał też, aby izolacja była rozwiązaniem współczesnych problemów kulturowych. Koncepcja kultury abp. Życińskiego zakładała integrację wspominanych trzech jej dziedzin, podkreślając znaczenie chrześcijaństwa $\mathrm{z}$ mocno zakorzenionymi w nim wartościami

44 J. Życiński, Trzy kultury, Poznań 1990, s. 119.

45 L. Dyczewski, Kultura w całościowym planie rozwoju, Warszawa 2011, S. $190-192$. 
uniwersalnymi. Wspólny wysiłek w przypominaniu źródeł kultury europejskiej może być ważnym zadaniem dla środowiska naukowego, artystycznego i religijnego, przypinaniem podstawowego zbioru wartości uniwersalnych.

\section{Etos sokratejski}

Postawa Sokratesa naznaczona jest troską o godność człowieka i personalistyczny wymiar społeczeństwa i kultury. Arcybiskup Życiński często sam odwoływał się do słów znanego polskiego socjologa Floriana Znanieckiego, ukazującego dwie alternatywne i opozycyjne wobec siebie możliwości przyszłego rozwoju kultury: albo cywilizacja wszechludzka, albo rozpad cywilizacji narodowych i pustka. Twórczość akademicka i duszpasterska Józefa Życińskiego jest wyrazem troski o godność osoby ludzkiej, poszukiwania wspólnoty aksjologicznej oraz dialogiem ze współczesną kulturą, co pozwala z optymizmem patrzeć w przyszłość, przezwyciężając programową pustkę.

Józefa Życińskiego koncepcja życia społecznego układa się w pewną harmonijną całość. Koncepcja osoby ludzkiej jest jej istotnym fundamentem. Człowiek w jego myśli jest ukazany na tle współczesnych odkryć nauk przyrodniczych i jest obywatelem trzech ojczyzn wyznaczonych przez środowisko biologiczne, predyspozycję kulturową oraz świat wartości religijnych ${ }^{46}$. Źródeł godności człowieka poszu-

${ }^{46}$ J. Życiński, Bóg i stworzenie. Zarys teorii ewolucji, dz. cyt., s. 68. 
kuje w humanizmie chrześcijańskim, humanizmie zakorzenionym w innych religiach oraz w humanizmie laickim. W ten sposób otwierał nie tylko Kościól jako instytucję na współczesną naukę, ale również myśl akademicką na poszukiwanie sensu ludzkiego życia poza nauką, nie rezygnując $\mathrm{z}$ racjonalnego myślenia. $\mathrm{W}$ swoich analizach odwoływał się zarówno do argumentacji religijnej, jak i pozareligijnej, aby tworzyć przestrzeń do spotkania i dyskusji z różnymi środowiskami. Było to wyrazem jego troski o poszukiwanie wspólnych wartości, które uczynią współczesny świat bardziej ludzkim. Podkreślanie znaczenia uniwersalnej roli wartości nie miało przy tym znamion narzucania własnych przekonań religijnych, ale było wyrazem troski o wspólną ludzką ekologię, nie sprowadzając jej wszelako do wymiaru czysto biologicznego. To poszukiwanie aksjologicznego fundamentu jest ważnym zadaniem współczesnej kultury, a jej całościowe ujęcie i unifikacja pozwolą przezwyciężyć fragmentaryzację ludzkiego doświadczenia. Łatwiej wówczas odnaleźć sens, o którym abp. Życiński tak często pisał i mówił. Wydaje się, że myśl jego cechuje się poszukiwaniem pewnej harmonii lub - pisząc językiem bardziej poetyckim - symfonii.

Arcybiskup z Lublina w swoich tekstach często nawiązywał do postawy sokratejskiej, nierzadko ją nawet dookreślał, sprowadzając do następujących wskaźników: odrzucenie relatywizmu prawdy i wartości nawet za cenę własnego życia, możliwość uzyskania indywidualnej doskonałości, odrzucenie stylu natchnionego guru, otwarcie 
na odkrywanie prawdy oraz przyjęcie dialogu jako metody krytycznego wyrażania argumentów, traktowanie poszukiwania prawdy jako niekończącego się procesu i optymizm poznawczy oraz przekonanie o możliwości zdobywania ideałów etycznych ${ }^{47}$. Ważnym elementem myśli Sokratesa był uniwersalizm zastosowań. W dialogu, cechującym się kulturą i prowadzonym metodycznie, odkrywano prawdę o świecie i człowieku. Wspomniane elementy dostrzec można w postawie Józefa Życińskiego. Akcent kładł na postawę racjonalną, poszukiwanie uniwersalizmu, jednoczącego niekiedy odległe dziedziny wiedzy, oraz otwartość na dialog z osobami o odmiennych poglądach i przekonaniach religijnych, czego symbolem są Kongresy Kultury Chrześcijańskiej w Lublinie. To one na długo przed organizowanymi przez Watykan „Dziedzińcami pogan” odbywały się na KUL-u w Lublinie, często dzięki niezwykłej determinacji abp. Życińskiego.

Jak już wspomniano, Życiński kategorie prawdy i piękna uczynił ważnymi elementami swojej działalności naukowej i duszpasterskiej. Ten fragment pozbawiony będzie przypisów, bo wypływa z doświadczenia wspólnej życiowej wędrówki osoby piszącej te słowa z Józefem Życińskim. Przyglądając się ostatnim latom jego życia, choćby przez uczestnictwo wraz z nim w rozmaitych, czasami wielogodzinnych spotkaniach, można było dostrzec pełną harmonię. Nie tylko pisał o godności człowieka, ale

${ }_{47}$ J. Życiński, Medytacje sokratejskie, dz. cyt., s. 7. 
potrafił, czasami narażając siebie, bronić drugiego człowieka. Nie tylko analizował kategorie solidarności międzyludzkiej w procesach globalizacyjnych, ale sam realnie pomagał ubogim, np. zapraszając na wieczerzę wigilijną do domu biskupiego ludzi samotnych czy dzieci z domu dziecka, i to zarówno wierzących, jak i niewierzących, chrześcijan i muzułmanów. W swoich tekstach często nawiązywał do słów Whiteheada o symfonii bosko-ludzkiej. Jego życie tworzyło harmonię czynów z wartościami przez siebie uznawanymi i propagowanymi. Można tu dostrzec ważny element postawy sokratejskiej. W ten sposób w naszych rozważaniach pojawia się kategoria dobra, która staje się równie istotna jak prawda i piękno. Mamy po raz kolejny do czynienia z syntezą prawdy, dobra i piękna, które razem tworzą życiową harmonię. 